\section{Interest Groups and the United Nations (UN)}

\author{
Lisa Maria Dellmuth \\ Department of Economic History and \\ International Relations, Stockholm University, \\ Stockholm, Sweden
}

\author{
Keywords \\ Advocacy groups $\cdot$ Civil society \\ organizations $\cdot$ Global governance $\cdot$ Interest \\ groups $\cdot$ International non-governmental \\ organizations $\cdot$ Multistakeholder \\ arrangements $\cdot$ Non-state actors · \\ Partnerships $\cdot$ Stakeholders $\cdot$ Transnational \\ actors $\cdot$ United Nations
}

\section{Definition}

Some of the most exciting controversies about transnational interest group politics revolve around the United Nations (UN), a major incubator of ideas and a hub in global governance. This article foregrounds interest groups in the $\mathrm{UN}$ as private voluntary organizations pursuing political advocacy. Anchored in political science, this definition views interest groups as a subset of "transnational actors," which are typically more broadly referred to as any type of individual or collective "non-state actor" that is transnationally active and neither a state nor composed of states. Interestingly, a growing number of comparative politics and international relations scholars have highlighted the overlap between "interest groups" and "international non-governmental organizations (INGOs)," as both types of organizations typically seek to balance self-interested advocacy and normative aims. Drawing from both interest group and INGO research, this article discusses three core topics: political opportunity structures, interest group strategies, and effects of interest groups. It discusses some evidence from the UN, identifies knowledge gaps, and problematizes imbalances in interest group involvement and effects in the UN. Understanding the academic debate in interest group and INGO research around these themes is timely and important amidst UN reform debates on the occasion of the organization's 75th anniversary in 2020 .

\section{Introduction}

The United Nations (UN) is an organizational hub in global governance and a major incubator of ideas and policies worldwide. It is thus crucial to understand how and why interest groups are involved in the UN, and to what effects.

Since its inception in 1945, the UN has actively involved interest groups in its policy-making. Article 71 of the Charter enables the Economic and Social Council (ECOSOC) to create rules for how to include "non-governmental organizations." The consultative status with ECOSOC is one of the earliest examples of stakeholder access 
to global governance, and the UN remains among the most accessible international institutions (Tallberg, Sommerer, Squatrito, \& Jönsson, 2013). However, the UN is a complex institution in which openness to interest groups varies across agencies, bodies, funds, and programs. In some issue areas, the UN is in fact less open than other international institutions. In environmental governance, for example, the European Union (EU) is more open to interest groups than the United Nations Framework Convention on Climate Change (UNFCCC) (Hadden, 2015).

Some of the most exciting controversies around global interest group politics revolve around the UN. Interest groups today work with the UN Secretariat, programs, funds, and agencies in various ways, including ECOSOC and its subsidiary bodies, secretariat offices, the Department of Public Information, conferences of the parties to various international agreements, and in consultation with UN member states. Interest groups exercise formal access rights and more informal practices of interaction, such as information retrieval from member state delegations and lobbying of international policy-makers. They are involved at various stages of the policy-making process, such as agenda setting, implementation, and monitoring, and across issue areas, such as environmental, human rights, and security cooperation. Their effects in global governance, through political opportunity structures in the $\mathrm{UN}$, are clear and measurable (Dellmuth \& Bloodgood, 2019).

The study of interest groups in the UN engages with both theories of interest groups and "international non-governmental organizations (INGOs)." INGOs have long been viewed as voluntary collective organizations that pursue the public interest, excluding interest groups such as industry associations or labor unions. Yet, a relatively recent and thriving body of international relations research has highlighted INGOs' practical motivations and organizational imperatives for survival (see chapter on " $>$ International NGOs"). A growing number of scholars has referred to INGOs as "advocacy organizations" (Prakash \& Gugerty, 2010), "non-governmental organizations" (Tallberg, Dellmuth, Agné, \& Duit, 2018), "international non-governmental advocacy organizations" (Bloodgood, 2011), and "transnational lobbyists" (Hanegraaff, Beyers, \& De Bruycker, 2016). There is a growing consensus to use the notions of "INGOs" and "interest groups" as synonyms or at least to recognize the overlap between the two categories of actors, backed by empirical evidence that INGOs typically seek to balance strategic and normative aims (e.g., Bob 2005, Bloodgood 2011, Dellmuth and Bloodgood 2019).

This article discusses three core topics in the interest groups and INGO literatures: political opportunity structures, interest group strategies, and effects of interest groups in the UN. Understanding the academic debate around these three themes is timely in light of UN reform on the occasion of the organization's 75th anniversary in 2020 .

\section{Political Opportunity Structures for Interest Groups in the UN}

The notion of "political opportunity structures" refers to the institutional, resource-related, and policy factors shaping interest group politics. It originally emerged in social movements research and is widely used in INGO research (Dellmuth \& Bloodgood, 2019).

\section{Institutional Factors}

It is useful to distinguish between formal and informal institutional arrangements for interest group involvement in the UN. "Formal access" refers to codified rights, such as the right to speak at official meetings, while "informal access" is based on norms and practices of engagement with international policy-makers and practitioners.

The main route to formal access to the $\mathrm{UN}$ is an application for consultative status with ECOSOC within the UN Department of Economic and Social Affairs (DESA). Consultative status provides interest groups with access to not only ECOSOC but also to its many subsidiary bodies, to the various human rights mechanisms of the United Nations, ad hoc processes on small arms, 
and special events organized by the President of the General Assembly. Yet many UN institutions have separate formal access rules, creating an institutional landscape of complex and overlapping institutions. Examples of the UN's decentralized system of accreditation rules are UN Environment, UN Global Compact, the UN Framework Convention on Climate Change (UNFCCC), and the regional fisheries management organizations operating under the auspices of the UN Convention of the Law of the Sea (UNCLOS).

One of the distinct hallmarks of INGOs is that they have the capacity to "boomerang" around formal institutional obstacles, as they are able to use their networks to ally with likeminded actors to pressure for policy change, both at the domestic and at the global level (Keck \& Sikkink, 1998, 19-25). As a result, interest groups depend less on formal access to the UN to impact global outcomes than they depend on access to domestic institutions to impact domestic outcomes. Indeed, as discussed below, interest groups active in relation to the UN typically combine activities within and outside the UN system (Dellmuth \& Tallberg, 2017).

\section{Resource Configurations}

According to the "resource exchange" model, policy-makers grant interest groups access to the policy process, while interest groups in return provide information that is useful to policymakers. This relationship is strategic. Both UN policy-makers and interest group representatives recognize that interest groups have a strategic incentive to present specialized information in such a way that it benefits their cause. Policymakers will therefore try to establish mechanisms they can use to evaluate the reliability of interest groups and their information (Lucas, Hanegraaff, \& De Bruycker, 2019).

Such screening mechanisms may be imperfect, because of the costs of establishing full control. At the end of the day, UN policy-makers are likely to accept the remaining risk of bias, given the benefits of outsourcing information collection to interest groups (Tallberg et al., 2018). Prime examples for such resource exchange in the $\mathrm{UN}$ are initiatives for involving corporations in climate adaptation such as the UNFCCC's Private Sector Initiative and the UN's Caring for the Climate Initiative, which are build on the explicit expectation that corporations contribute with financial resources, develop new technologies and innovative solutions, and engage in public-private partnerships.

\section{Policy Environments}

The UN deals with policy issues in a wide range of policy sectors, including development, disaster relief, energy, environmental affairs, health, human rights, migration, and peace and security. The complexity of a policy issue is relevant for interest groups when considering how to get involved. For example, complexity may arise from the number of distinct actors involved (e.g., public agencies, non-state actors, and partnerships), policy sectors affected (e.g., issues at the climate-conflict or climate-health nexus), the extent to which technical knowledge is needed to diagnose or solve the problem (e.g., in climate-induced migration, scientific knowledge is typically perceived to be more uncertain than in the area of climate-health), and the fragmentation of the institutional context or regime (e.g., environmental governance is commonly understood to be more complex than security governance).

The greater the complexity of a policy problem, the more likely it is that UN policy-makers will lack sufficient information, and the greater the probability that they will rely on interest groups' information to make decisions (Tallberg et al., 2018). The complex nature of the policy problems dealt with by the UN also implies much space for interest groups to pursue advocacy, for example, new coalitions may arise that are built on different aspects of an issue and that may work against each other (Hadden, 2015). Coalition building may also increase interest group effects on UN policy-making and implementation as groups join forces to compensate for individual weaknesses, as for example evidenced in the context of the UN-led Kyoto Protocol negotiations on global climate change and the United Nations Convention to Combat Desertification (Betsill \& Corell, 2008). 
In all, who benefits from these political opportunity structures? In the UN, the answer is clear: business organizations and medium-sized organizations (between about 3 and 50 permanent staff members) from the global north have most often access and influence (Petersson, Dellmuth, Merrie, \& Österblom, 2019; Dellmuth \& Tallberg, 2017), although interest group populations accredited to the UN include organizations from both the global south and north (Tallberg et al., 2018; Henry, Sundstrom, Winston, \& Bala-Miller, 2019). The following section focuses on the strategies adopted by these and other interest groups active in relation to the $\mathrm{UN}$.

\section{Interest Group Strategies in the UN}

Interest group strategies are best understood in terms of inside and outside lobbying. "Inside lobbying" refers to activities which aim to influence political outcomes through direct interaction with decision-makers, and "outside lobbying" (see chapter on " Outside Lobbying") to activities which aim to influence outcomes by putting pressure on policy-makers through the mobilization of public opinion without relying on UN access.

Many interest groups lack economic or coercive power and have in the past relied on outside strategies of normative pressure and information monitoring to shift state and international policymaker behavior via issue framing, agenda setting, and norm diffusion (e.g., Keck and Sikkink 1998 and Joachim 2007). However, evidence from representative samples of interest groups in the UN suggests that interest groups in the UN typically combine inside and outside strategies in the UN (Dellmuth \& Tallberg, 2017).

The nature of interest group strategies crucially depends on their goals, funding structure, and policy environment. First, interest groups rely more on inside lobbying the more they aim to influence the UN, relative to other goals, such as providing services or representing constituencies. For instance, interest groups in humanitarian aid, health, and education often have a service orientation, primarily cooperating with the $\mathrm{UN}$ in the implementation of policy programs. Other groups, such as those acting on behalf of indigenous communities, young people and women, have a representation orientation, primarily expressing the interests of their specific constituency vis-à-vis the UN (Dellmuth \& Tallberg, 2017).

Second, groups that do not depend on membership funding rely more often on inside lobbying than their membership-funded counterparts that have more incentives to increase their visibility among stakeholders (Hanegraaff et al., 2016). Third, the public salience of a negotiated political issue matters. UN policy-making is not publicly salient that often, so that interest groups will seek to influence policy-makers with opposing views rather than like-minded policymakers when a UN issue does become salient, as this presents a window of opportunity for groups to persuade opponents (Beyers \& Hanegraaff, 2017).

\section{Interest Group Effects in the UN}

Interest group "effects" or "impacts" are broadly defined as any changes in global governance attributable to interest groups (Risse, 2012; Dellmuth \& Bloodgood, 2019). For example, INGOs have been shown to have an impact in global governance with respect to norm and information diffusion, changing state behavior, and issue framing. Civil society organizations and their networks have, for example, brought about a climate justice lens in the UNFCCC and in related global climate change policies (Hadden, 2015), and a shift in discourse from "equality" to the "women in development" frame in the UN (Joachim, 2007).

A narrower concept is "influence" (see chapter on " Influence"), which denotes the part of policy decisions that is different from what it would have been had interest groups not been involved in decision-making (Betsill \& Corell, 2008; Tallberg et al., 2018). For example, Lucas et al. (2019) apply a resource exchange perspective to policy-making in the context of the UNFCCC and observe that policy-makers in the UN climate conferences seek out advocacy groups more 
when they are faced with increased levels of political pressure, as is, for example, the case with elected politicians, raising prospects for influence.

While there are still only few studies of interest group influence in the UN when compared to interest group influence at the domestic level, there are two main categories of factors that have been shown to condition interest group influence in the UN: interest group characteristics and the policy environment.

\section{Interest Group Characteristics}

From a resource exchange perspective, the demand for information and other resources held by interest groups is crucial (Tallberg et al., 2018; Lucas et al., 2019). Critical observers have discussed the unequal impact of business organizations compared to civil society organizations on new forms of global governance related to the $\mathrm{UN}$, such as public-private partnership sessions at the UN Conference on Trade and Development. Yet the effects of such biased interest representation on the democratic credentials of the UN are debated (Risse 2012; Agné, Dellmuth, \& Tallberg, 2015; Gleckman, 2018

\section{Policy Environment}

Existing research highlights three main aspects of policy environments. First, the UN deals with a large range of issue areas. Yet, the evidence from different issue areas, such as commodities and trade, development, environment, health, human rights, and security, suggests that on average, issue variation matters less for interest group influence on UN policy-making than information-access exchange (Tallberg et al., 2018). However, research comparing interest group influence across different issue areas in the UN is still in its infancy. Second, when comparing impact across different stages of the policy cycle, the evidence from a large number of studies in international relations is clear: taken together, impact is greatest in the agenda-setting stage (e.g., Keck and Sikkink 1998, Joachim 2007; see Risse 2012, for an overview). Third, the UN is characterized by a strikingly complex, overlapping, and changing web of institutions. Interest groups face many emerging and transforming opportunities for joining private or public-private partnerships under the auspices of the UN - also referred to as multistakeholder or intersectoral partnerships whose effects on the democracy and effectiveness of UN policy-making are highly debated (e.g., Pattberg, Biermann, Chan, \& Mert, 2012; Gleckman 2018).

\section{Conclusion}

In conclusion, the UN is a political system with ample political opportunity structures for interest groups to get involved. At the same time, the UN is complex and changing, with interest groups facing considerable information asymmetries, resource dependencies, and other uncertainties when seeking to become involved. Amidst debates about UN reform on the organization's 75 th anniversary in 2020 , two general trends are worth emphasizing.

The first is that partnerships and multistakeholder arrangements within the UN system have gained in importance. We are currently witnessing a power shift from member state cooperation in the UN to governance arrangements lacking state oversight. Such governance arrangements provide opportunities for interest groups to cooperate with different kinds of state and nonstate actors, and in some instances to exert political authority, often across issue areas. We need more constructive debate about when these governance arrangements contribute to more democratic, legitimate, and effective global governance.

The second trend is that transnational corporations and groups from the global north have become big players in the UN. These actors have more often and more stable access to various UN forums. Access does not always lead to influence on policy-making and has often to do with interest groups collecting information for their stakeholders. But this trend still raises concerns that business and global north interests might "capture" UN policy-making, given that UN agencies typically depend on biased information provided by INGOs. 
These developments will continue to be relevant for debates about how to improve and reform UN policy-making in view of pressing global problems faced in the contemporary world.

\section{Cross-References}

European Commission (Blom-Hansen and
Senniger)
European Union (Hanegraaff)
Influence
International NGOs (Bloodgood)
Outside Lobbying/Outsider Strategies
- World Trade Organization (Hanegraaff and de
Bièvre)

\section{References}

Agné, H., Dellmuth, L. M., \& Tallberg, J. (2015). Does stakeholder involvement foster democratic legitimacy in international organizations? An empirical assessment of a normative theory. Review of International Organizations, 10(4), 465-488.

Betsill, M., \& Corell, E. (2008). NGO diplomacy: The influence of nongovernmental organizations in international environmental negotiations. Cambridge, MA: The MIT Press.

Beyers, J., \& Hanegraaff, M. (2017). Balancing friends and foes: Explaining advocacy styles at global diplomatic conferences. Review of International Organizations, 12, 461-484.

Bloodgood, E. A. (2011). The interest group analogy: International non-governmental advocacy organizations in international politics. Review of International Studies, 37(1), 93-120.

Bob, C. (2005). The marketing of rebellion. Cambridge, UK: Cambridge University Press.

Dellmuth, L. M., \& Bloodgood, E. A. (2019). Advocacy group effects in global governance: Populations, strategies, and political opportunity structures. Interest Groups \& Advocacy, 9(3), 255-269.

Dellmuth, L. M., \& Tallberg, J. (2017). Advocacy strategies in global governance: Inside vs. outside lobbying. Political Studies, 65(3), 705-723.

Gleckman, H. (2018). Multistakeholder governance and democracy. New York, NY: Routledge.
Hadden, J. (2015). Networks in contention: The divisive politics of global climate change. Cambridge, UK: Cambridge University Press.

Hanegraaff, M., Beyers, J., \& De Bruycker, I. (2016). Balancing inside and outside lobbying: The political strategies of lobbyists at global diplomatic conferences. European Journal of Political Research, 55(3), 568-588.

Henry, L. A., Sundstrom, L. M., Winston, C., \& BalaMiller, P. (2019). NGO participation in global governance institutions: International and domestic drivers of engagement. Interest Groups \& Advocacy, 8(3), 291-332.

Joachim, J. (2007). Agenda setting, the UN, and NGOs: Gender violence and reproductive rights. Washington, DC: Georgetown University Press.

Keck, M. E., \& Sikkink, K. (1998). Activists beyond Borders: Advocacy networks in international politics. Ithaca, NY: Cornell University Press.

Lucas, K., Hanegraaff, M., \& De Bruycker, I. (2019). Lobbying the lobbyists: When and why do policymakers seek to influence advocacy groups in global governance? Interest Groups \& Advocacy, 8 (3), 407-432.

Pattberg, P., Biermann, F., Chan, S., \& Mert, A. (Eds.). (2012). Public- private partnerships for sustainable development: Emergence, influence, and legitimacy. Cheltenham, UK: Edward Elgar.

Petersson, M., Dellmuth, L. M., Merrie, A. N., \& Österblom, H. (2019). Patterns and trends in non-state actor participation in regional fisheries management organizations. Marine Policy, 104, 146-156.

Prakash, A., \& Gugerty, M. K. (Eds.). (2010). Advocacy organizations and collective action. Cambridge, UK: Cambridge University Press.

Risse, T. (2012). Transnational actors and world politics. In W. Carlsnaes, T. Risse, \& B. A. Simmons (Eds.), Handbook of international relations (2nd ed.). London, UK: Sage.

Tallberg, J., Dellmuth, L. M., Agné, H., \& Duit, A. (2018). NGO influence in international organizations: Information, access, and exchange. British Journal of Political Science, 48, 213-238.

Tallberg, J., Sommerer, T., Squatrito, T., \& Jönsson, C. (2013). The opening up of international organizations: Transnational access in global governance. Cambridge, UK: Cambridge University Press.

\section{Further Reading}

Department of Economic and Social Affairs (DESA): NGO Branch. https://csonet.org.

UN and Non-Governmental Organizations (NGOs): A Quick Guide. https://research.un.org/en/ngo. 